\title{
Study on the Equilibria of the Complex Formation of the Ion-pair of Germanium(IV) with 4-Nitrocatechol and 1,4-Diphenyl-3-(phenylamino)-1H-1,2,4-triazole
}

\author{
Petya Racheva, ${ }^{1}$ Kirila Stojnova, ${ }^{2}$ Vidka Divarova ${ }^{1}$ and Vanya Lekova ${ }^{2, *}$ \\ ${ }^{1}$ Department of Chemical Sciences, Faculty of Pharmacy, Medical University-Plovdiv, \\ 15A Vasil Aprilov Boulevard, Plovdiv 4002, Bulgaria \\ ${ }^{2}$ Department of General and Inorganic Chemistry, Faculty of Chemistry, Plovdiv University "Paisii Hilendarski", \\ 24 Tsar Assen Street, Plovdiv 4000, Bulgaria \\ *Corresponding author: E-mail: vanlek@ uni-plovdiv.bg; \\ Tel.: +35932261420
}

Received: 18-01-2017

\begin{abstract}
The complex formation of the ion-pair formed between the anionic chelate of Ge(IV)-4-nitrocatechol (4-NC) and the cation of 1,4-diphenyl-3-(phenylamino)-1H-1,2,4-triazole (Nitron, Nt) in the liquid-liquid extraction system Ge(IV)-4$\mathrm{NC}-\mathrm{Nt}-\mathrm{H}_{2} \mathrm{O}-\mathrm{CHCl}_{3}$ was studied by spectrophotometry. The optimum extraction-spectrophotometric conditions for the complex formation were established. The validity of Beer's law was checked and some analytical characteristics of the system were calculated. The effect of co-existing ions and reagents on the process of complex formation was investigated. The association process in aqueous phase and the extraction equilibria were studied and quantitatively characterized. The following key constants of the processes were calculated: association constant, distribution constant, extraction constant and recovery factor. The molar ratio of the reagents was determined by independent methods. A reaction scheme and a general formula of the complex were suggested.
\end{abstract}

Keywords: Germanium(IV), nitron, ion-pair, chelate formation, extraction equilibriums

\section{Introduction}

The germanium and its compounds are widely used in various important areas of technology, science, and medicine. Germanium is present in all living plant and animal matter in micro-trace quantities and it is essential from a biochemical point of view. The germanium is relatively less toxic compared to many other metals. The accumulation of relatively high doses of germanium (milligram order of germanium per $1 \mathrm{~g}$ tissue) causes severe poisoning, including impairments in kidney, nerves, muscles. On the other hand, germanium deficiency can lead to seriously hematologic disorders and tumor formation. Pharmaceutical preparations, containing germanium are effectively applied in treatment of a wide range of serious afflictions, including cancer, arthritis, osteoporosis and acute renal failure. ${ }^{1-8}$

The germanium is a third row post-transition metal and its chemistry has developed considerably in the recent years, indicated by the large number of publications in the scientific literature. Germanium(IV) forms complexes with various natural organic ligands containing $\mathrm{O}, \mathrm{N}$ and $\mathrm{S}$ donor atoms such as polyphenols and their functional derivatives, polyhydroxycarboxylic acids, aminopolyhydroxycarboxylic acids, thiopolycarboxylic acids, 8hydroxyquinoline and its derivatives, aromatic derivates of hydroxyaldehydes and hydroxyketones, hydroxyazodyes. The complexes of germanium with chelate ligands containing $\mathrm{O}, \mathrm{N}$ and $\mathrm{S}$ donor atoms have diverse industrial, biological, pharmacological and medical applications. ${ }^{9-17}$ Germanium(IV) gives colored chelates with aromatic compounds, containing two or more hydroxyl groups in $o$-position relative to each other. The colored anionic chelates of Ge(IV) form ion-associated complexes with bulky organic cations, like tetradecyl(trihexyl)phosp-

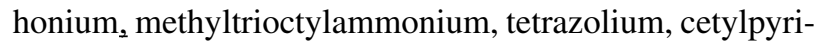
dinium, cetyltrimethylammonium, tetraphenylammonium, tetraphenylarsonium. ${ }^{18-25}$ 
Nitron (Nt) (1,4-diphenyl-3-(phenylamino)-1H1,2,4-triazole) is an organic compound containing a quaternary nitrogen atom included in a five-membered ring. ${ }^{26}$ The structure and properties of the nitron determine its ability to form ion-associated complexes with anionic chelates of metals. The bulky hydrophobic organic substituents in the molecule of the nitron increase the extractability of the ionassociated complexes. The presence of a quaternary nitrogen atom in the molecule of the nitron determines the ability to form ionic associates with chelates of metals in aqueous phase without protonation, as opposed to the amines. ${ }^{27-30}$ Nitron is an important reagent for the determination of nitrates, perchlorates, borates, or traces of gold. ${ }^{31-34}$

The liquid-liquid extraction is a part of the chemistry of the solutions and the coordination compounds. It is applied to study the processes of complex formation and the extraction equilibria. The extraction spectrophotometry is a relatively simple, convenient, rapid to perform and inexpensive method for preparation and characterization of new complex compounds as well as for their application in the chemical analysis. ${ }^{35-38}$

The aim of this research was to study spectrophotometrically the extraction equilibria of the complex formation of the ion-pair formed between the anionic chelate of $\mathrm{Ge}(\mathrm{IV})$-4-nitrocatechol (4-NC) and the cation of 1,4-diphenyl-3-(phenylamino)-1 $H$-1,2,4-triazole (Nitron, $\mathrm{Nt}$ ) in the liquid-liquid system $\mathrm{Ge}(\mathrm{IV})-4-\mathrm{NC}-\mathrm{Nt}-\mathrm{H}_{2} \mathrm{O}-\mathrm{CHCl}_{3}$ as well as to evaluate the possible applications of the system for determination of traces of germanium(IV) in alloys, biological, medical and pharmaceutical samples.

\section{Experimental}

\section{1. Reagents and Apparatus}

$\mathrm{GeO}_{2}$ (Sigma-Aldrich, Munich, Germany, p.a.): A 2.0 $\times 10^{-3} \mathrm{~mol} \mathrm{~L}^{-1}$ aqueous solution of Ge(IV) was prepared by dissolving $\mathrm{GeO}_{2}$ in water upon moderate heating. 4-Nitrocatechol (4-NC) (Sigma-Aldrich, p.a.): 4-NC was dissolved in distilled water to give a $1.0 \times 10^{-2} \mathrm{~mol} \mathrm{~L}^{-1}$ solution. 1,4Diphenyl-3-(phenylamino)-1H-1,2,4-triazole (Nitron, Nt) (95\%, Alfa Aesar GmbH \& Co KG, Germany): A chloroform $3.4 \times 10^{-4} \mathrm{~mol} \mathrm{~L}^{-1}$ solution was prepared. The acidity of the aqueous medium was set using a buffer solution prepared by mixing $2.0 \mathrm{~mol} \mathrm{~L}^{-1}$ aqueous solutions of $\mathrm{CH}_{3} \mathrm{COOH}$ and $\mathrm{NH}_{4} \mathrm{OH}$. The organic solvent $\mathrm{CHCl}_{3}$ was additionally distilled. The $\mathrm{pH}$ was checked by $\mathrm{HI} 83140 \mathrm{pH}$ meter (Romania). A Camspec M508 spectrophotometer (United Kingdom), equipped with $10 \mathrm{~mm}$ path length cells, was employed for measurement of the absorbance.

\section{2. Procedure for Establishment of the Optimum Extraction-Spectrophotometric Conditions}

The required aliquots of the solutions of Ge(IV),
4-NC and buffer needed to adjust the $\mathrm{pH}$ of the aqueous phase were introduced into $250 \mathrm{~cm}^{3}$ separatory funnels. The resulting solutions were diluted with distilled water to a total volume of $10 \mathrm{~cm}^{3}$. A required aliquot of a chloroform solution of Nitron was added and then the organic phase was brought up to $10 \mathrm{~cm}^{3}$ with chloroform. The funnels were shaken for a defined time. A portion of the organic extract was filtered through a filter paper into a 1 $\mathrm{cm}$ cell and its absorbance was measured against a blank run in parallel.

\section{3. Procedure for Determination of the Distribution Constant}

The distribution constant $\left(K_{D}\right)$ was determined from the ratio $K_{D}=A_{1} /\left(A_{3}-A_{1}\right)$, where $A_{1}$ and $A_{3}$ are the absorbance (measured against blanks) obtained after a single and triple extraction, respectively. The single extraction and the first stage of the triple extraction were performed under the optimum conditions for complex formation (Table 1, column 1). The organic layers were transferred into $25 \mathrm{~cm}^{3}$ calibrated flasks and the flask from the single extraction was brought to volume with chloroform. The second stage of the triple extraction was performed by ad$\operatorname{ding} 7 \mathrm{~cm}^{3}$ of chloroform to the aqueous phase that remained after the first stage. After extraction, the obtained extract was added to this first stage of the triple extraction. The third stage of the triple extraction was performed in the same manner as for the second stage and the extract was added to those of the first two stages. The volume of the flask was brought to the mark with chloroform. The calibrated flasks were shaken before the spectrophotometric measurements. ${ }^{30}$

\section{Results and Discussion}

\section{1. Optimum Extraction-Spectrophotometric Conditions}

The absorption spectrum of the extract of the studied ion-pair formed between the anionic chelate of $\mathrm{Ge}(\mathrm{IV})$ with 4-NC and nitronium cation in $\mathrm{CHCl}_{3}$ was characterized by an absorption maximum in the visible range $\left(\lambda_{\max }=405 \mathrm{~nm}\right)$ (Figure 1). The influence of the acidity of the aqueous phase on the extraction of the anionic chelate $\mathrm{Ge}(\mathrm{IV})-4-\mathrm{NC}$ into the organic phase in the form of an ion-pair with the nitronium cation was investigated. The maximum and constant extraction of the ion-associated complex is achieved in the $\mathrm{pH}$ range from 3.0 to 4.5 . Acetate buffer solution with $\mathrm{pH}=4.0$ was used in all further experiments. The results showed that the extraction equilibrium is achieved for shaking time of not less than $60 \mathrm{~s}$. A longer shaking time did not affect the absorbance. The experiments were performed for $2 \mathrm{~min}$. The concentrations of the reagents are the most important factor inf- 


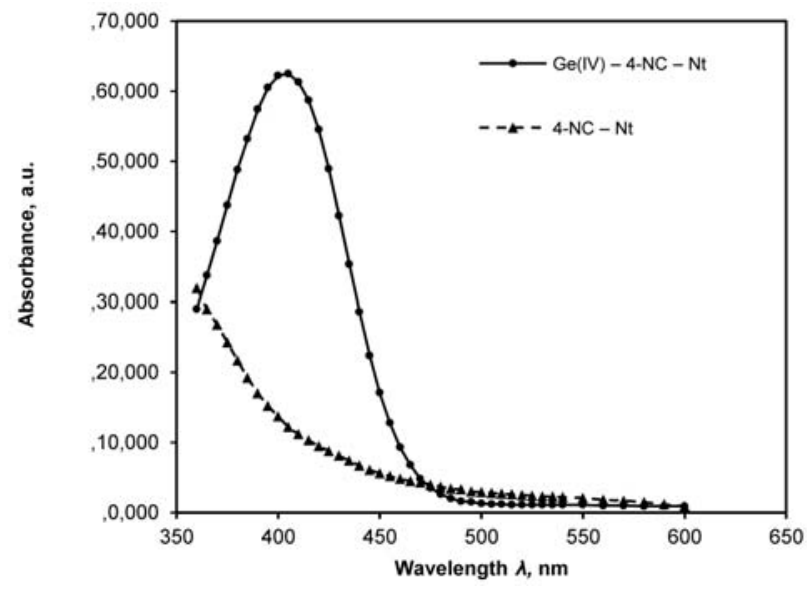

Figure 1. Absorption spectra of the complex Ge(IV)-4-NC-Nt and of the blank sample 4-NC-Nt in $\mathrm{CHCl}_{3} . C_{\text {Ge(IV) }}=2.0 \times 10^{-5} \mathrm{~mol}$ $\mathrm{L}^{-1} ; C_{4-\mathrm{NC}}=5.0 \times 10^{-4} \mathrm{~mol} \mathrm{~L}^{-1} ; C_{\mathrm{Nt}}=1.7 \times 10^{-4} \mathrm{~mol} \mathrm{~L}^{-1} ; \mathrm{pH}=4.0$; $\lambda=405 \mathrm{~nm} ; \tau=2 \mathrm{~min}$

luencing the extraction equilibria. The chelate formation of Ge(IV)-4-NC requires 15.0-fold excess of 4-NC $\left(C_{4-\mathrm{NC}}\right.$ $\left.\geq 3.0 \times 10^{-4} \mathrm{~mol} \mathrm{~L}^{-1}\right)$ and 5.1-fold excess of Nitron $\left(C_{\mathrm{Nt}} \geq\right.$ $\left.1.0 \times 10^{-4} \mathrm{~mol} \mathrm{~L}^{-1}\right)$ for maximum association and extraction. The optimum experimental conditions for the extraction of the ion-associated complex are summarized in Table 1, column 1 .

\section{2. Beer's Law, Apparent Molar Absorptivity and Other Analytical Characteristics}

The range of obedience to Beer's law, i.e. the linear relationship between the germanium(IV) concentration in the aqueous phase $\left(C_{\mathrm{Ge}(\mathrm{IV})}, \mu \mathrm{g} \mathrm{mL} \mathrm{m}^{-1}\right)$ and the absorbance of the ion-association complex in the organic phase after extraction was studied using regression analysis under the optimum conditions for complex formation. The equation of a straight line was found to be $\mathrm{Y}=0.3807 \mathrm{X}+0.0483$ with a correlation coefficient squared 0.9982 . Under the optimum conditions for complex formation, the linearity is observed for concentrations up to $5.81 \mu \mathrm{g} \mathrm{cm}^{-3} \mathrm{Ge}$ (IV). Further analytical characteristics, such as apparent molar absorptivity $\varepsilon^{\prime}$, adherence to Beer's law, Sandell's sensitivity, limit of detection and limit of quantification, are shown in Table 1, column 2.

\section{3. Effect of Co-existing Ions and Reagents on the Complex Formation}

The effect of various co-existing ions and reagents on the process of complex formation of the ion-pair formed between the anionic chelate Ge(IV)-4-NC and nitronium cation was studied under optimum extraction conditions (Table 1, column 1). The concentration of Ge(IV) in the presence of the co-existing ions and reagents was determined from the sequence of Beer's law. A deviation of $\pm 3 \%$ from the absorbance of the ion-associate in the absence of co-existing ions was accepted as an interfering effect. The results are presented in Table 2. From them, it can be concluded that most of the ions studied do not interfere, but some of them, like $\mathrm{Br}^{-}, \mathrm{F}^{-}, \mathrm{I}^{-}, \mathrm{C}_{6} \mathrm{H}_{5} \mathrm{O}_{7}{ }^{2-}, \mathrm{NO}_{3}^{-}$, $\mathrm{C}_{2} \mathrm{O}_{4}{ }^{2-}$ and complexone III in concentrations higher than the indicated ones, hinder the extraction of Ge(IV) as an associated complex with 4-NC and Nitron. The extraction equilibrium is hindered by $\mathrm{Al}(\mathrm{III}), \mathrm{Cr}(\mathrm{III}), \mathrm{Cr}(\mathrm{VI}), \mathrm{Fe}(\mathrm{III})$, $\mathrm{Mo}(\mathrm{VI}), \mathrm{W}(\mathrm{VI})$ and $\mathrm{V}(\mathrm{V})$. The interfering ions can be masked or removed from the extraction system to avoid this. Our investigations as well as the studies published in the literature show that the some of the co-existing ions, like $\mathrm{Al}(\mathrm{III}), \mathrm{Cr}(\mathrm{III})$ and $\mathrm{Fe}(\mathrm{III})$ can be removed by their preprecipitation with $\mathrm{OH}$ at $\mathrm{pH}=11$. The co-existing ions, like Mo(VI) and $\mathrm{W}(\mathrm{VI})$ can be masked with added L-ascorbic acid, Complexone III, $\mathrm{C}_{6} \mathrm{H}_{5} \mathrm{O}_{7}{ }^{2-}$ or $\mathrm{C}_{2} \mathrm{O}_{4}{ }^{2-}$ in concentrations lower than the indicated. ${ }^{39} \operatorname{Vanadium}(\mathrm{V})$ can be co-precipitated with $\mathrm{Fe}(\mathrm{III})$ in alkali medium. ${ }^{40}$

\section{4. Molar Ratios of the Complex, Reaction Scheme and Suggested General Formula}

The molar ratios of the complex were determined by three independent methods. The straight-line method of

Table 1. Optimum extraction-spectrophotometric conditions and analytical characteristics of the system $\mathrm{Ge}(\mathrm{IV})-4-\mathrm{NC}-\mathrm{Nt}-\mathrm{H}_{2} \mathrm{O}-\mathrm{CHCl}_{3}$

\begin{tabular}{ll}
\hline Optimum Conditions & Analytical Characteristic \\
\hline $\begin{array}{l}\text { Absorption maximum }\left(\lambda_{\max }\right) 405 \mathrm{~nm} \\
(2.98 \pm 0.11) \times 10^{4} \mathrm{~L} \mathrm{~mol}^{-1} \mathrm{~cm}^{-1}\end{array}$ & Apparent molar absorptivity $\left(\varepsilon^{\prime}\right)$ \\
$\begin{array}{l}\text { Volume of the aqueous phase } 10 \mathrm{~cm}^{3} \\
(3.09 \pm 0.25) \times 10^{4} \mathrm{~L} \mathrm{~mol}^{-1} \mathrm{~cm}^{-1}\end{array}$ & True molar absorptivity $(\varepsilon)$ \\
Volume of the organic phase $10 \mathrm{~cm}^{3}$ & Sandell's sensitivity (SS) $2.43 \mathrm{ng} \mathrm{cm}^{-2}$ \\
pH of the aqueous phase $3.0 \div 4.5$ & Adherence to Beer's law \\
up to $5.81 \mu \mathrm{g} \mathrm{cm}-3$ & Relative standard deviation (RSD) $1.01 \%$ \\
Shaking time $(\tau) 2 \mathrm{~min}$ & Limit of detection (LOD) $0.34 \mu \mathrm{g} \mathrm{cm}$ \\
Concentration of $4-\mathrm{NC} \geq 3.0 \times 10^{-4} \mathrm{~mol} \mathrm{~L}^{-1}$ & Limit of quantification (LOQ) $1.13 \mu \mathrm{g} \mathrm{cm}^{-3}$ \\
Concentration of $\mathrm{Nt} \geq 1.0 \times 10^{-4} \mathrm{~mol} \mathrm{~L}^{-1}$ &
\end{tabular}


Table 2. Effect of co-existing ions and reagents on the complex formation of the ion-associate $\mathrm{Ge}(\mathrm{IV})-4-\mathrm{NC}-\mathrm{Nt}$ for extraction in the presence of $14 \mu \mathrm{g} \mathrm{Ge}(\mathrm{IV})$

\begin{tabular}{|c|c|c|c|}
\hline $\begin{array}{l}\text { Co-existing ion } \\
\text { and reagent }\end{array}$ & $\begin{array}{l}\text { Co-existing ion and reagent, } \\
\mu \mathrm{g} / 10 \mathrm{~cm}^{3} \text { aqueous phase }\end{array}$ & $\begin{array}{c}\mathbf{G e}\left({ }^{2} \mathrm{~V}\right) \\
\text { found, } \mu \mathrm{g}\end{array}$ & $\mathrm{R}, \%$ \\
\hline$\overline{\mathrm{Na}^{+}}$ & 10000 & 14.30 & 102.14 \\
\hline $\mathrm{K}^{+}$ & 10000 & 13.75 & 98.21 \\
\hline $\mathrm{Cu}^{2+}$ & 10000 & 14.23 & 101.64 \\
\hline $\mathrm{Zn}^{2+}$ & 10000 & 14.38 & 102.71 \\
\hline $\mathrm{Cd}^{2+}$ & 10000 & 13.92 & 99.43 \\
\hline $\mathrm{Ni}^{2+}$ & 10000 & 14.09 & 100.64 \\
\hline $\mathrm{Mn}^{2+}$ & 10000 & 14.19 & 101.36 \\
\hline $\mathrm{Co}^{2+}$ & 10000 & 13.66 & 97.57 \\
\hline $\mathrm{Al}^{3+}$ & 20 & & interference \\
\hline $\mathrm{Cr}^{3+}$ & 20 & & interference \\
\hline $\mathrm{Fe}^{3+}$ & 20 & & interference \\
\hline $\mathrm{V}(\mathrm{V})$ & 10 & & interference \\
\hline $\mathrm{Cr}(\mathrm{VI})$ & 30 & & interference \\
\hline $\mathrm{W}(\mathrm{VI})$ & 20 & & interference \\
\hline $\mathrm{Mo}(\mathrm{VI})$ & 30 & & interference \\
\hline $\mathrm{F}^{-}$ & 100 & 14.31 & 102.21 \\
\hline $\mathrm{Cl}^{-}$ & 10000 & 14.18 & 101.29 \\
\hline $\mathrm{Br}^{-}$ & 3500 & 14.39 & 102.79 \\
\hline $\mathrm{I}^{-}$ & 5000 & 14.26 & 101.86 \\
\hline $\mathrm{NO}_{3}^{-}$ & 2500 & 13.83 & 98.79 \\
\hline $\mathrm{PO}_{4}^{3-}$ & 10000 & 13.97 & 99.79 \\
\hline $\mathrm{C}_{2} \mathrm{O}_{4}^{2-}$ & 500 & 14.37 & 102.64 \\
\hline $\mathrm{C}_{6} \mathrm{H}_{5} \mathrm{O}_{7}^{3-}$ & 400 & 13.72 & 98.00 \\
\hline Complexone 222 & 3000 & 14.38 & 102.71 \\
\hline L- Ascorbic acid & 10000 & 13.80 & 98.57 \\
\hline
\end{tabular}

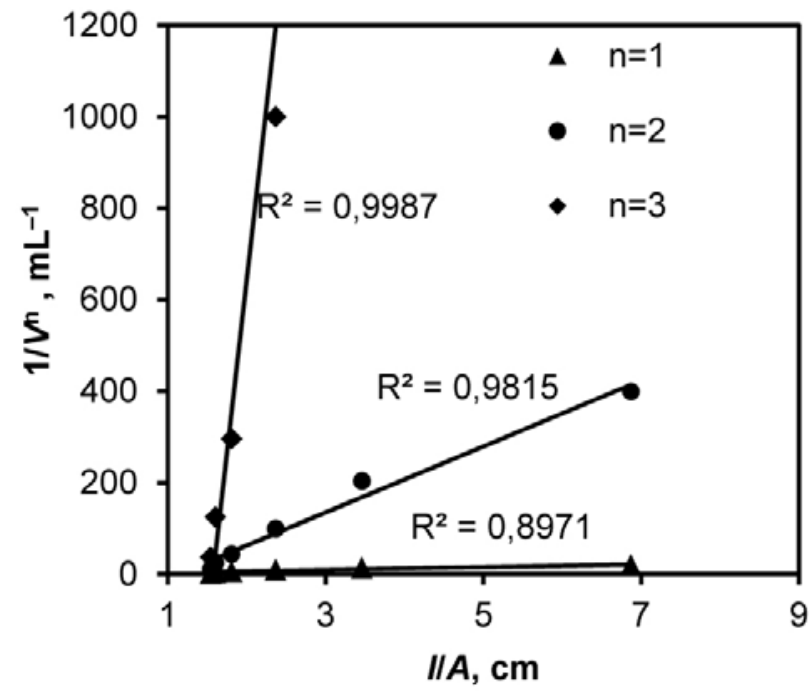

Figure 2. Determination of the molar ratio (n) Ge(IV):4-NC by the method of Asmus. $C_{\mathrm{Ge}(\mathrm{IV})}=2.0 \times 10^{-5} \mathrm{~mol} \mathrm{~L}^{-1} ; C_{\mathrm{Nt}}=1.7 \times 10^{-4} \mathrm{~mol}$ $\mathrm{L}^{-1} ; \mathrm{pH}=4.0 ; \lambda=405 \mathrm{~nm} ; \tau=2 \mathrm{~min}$

Asmus and the mobile equilibrium method were applied to prove the molar ratios $\mathrm{Ge}(\mathrm{IV}): 4-\mathrm{NC}$ and $\mathrm{Ge}(\mathrm{IV}): \mathrm{Nt}^{41}$ The results from the application of these methods are shown in Figures $2 \div 4$, respectively. On the basis of the results it can be concluded that Ge(IV), 4-NC and Nitron in-

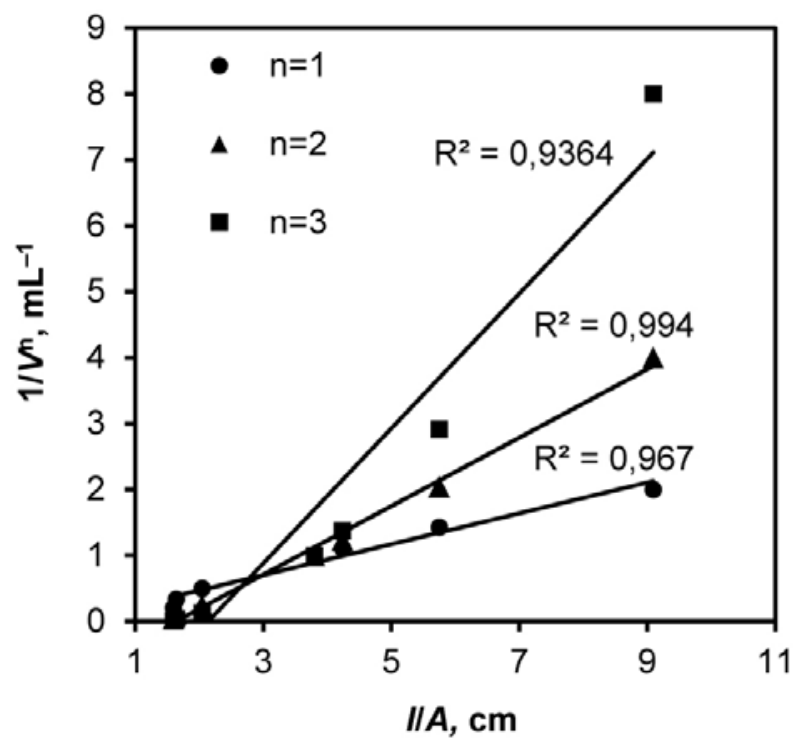

Figure 3. Determination of the molar ratio (n) Ge(IV): Nt by the method of Asmus. $C_{\mathrm{Ge}(\mathrm{IV})}=2.0 \times 10^{-5} \mathrm{~mol} \mathrm{~L}^{-1} ; C_{4-\mathrm{NC}}=5.0 \times 10^{-4}$ $\mathrm{mol} \mathrm{L}^{-1} ; \mathrm{pH}=4.0 ; \lambda=405 \mathrm{~nm} ; \tau=2 \mathrm{~min}$

teract in molar ratio 1:3:2. The application of the method of continuous variations confirmed the molar ratio $\mathrm{Ge}(\mathrm{IV}): \mathrm{Nt}=1: 2\left(\right.$ Figure 5). ${ }^{41}$ 


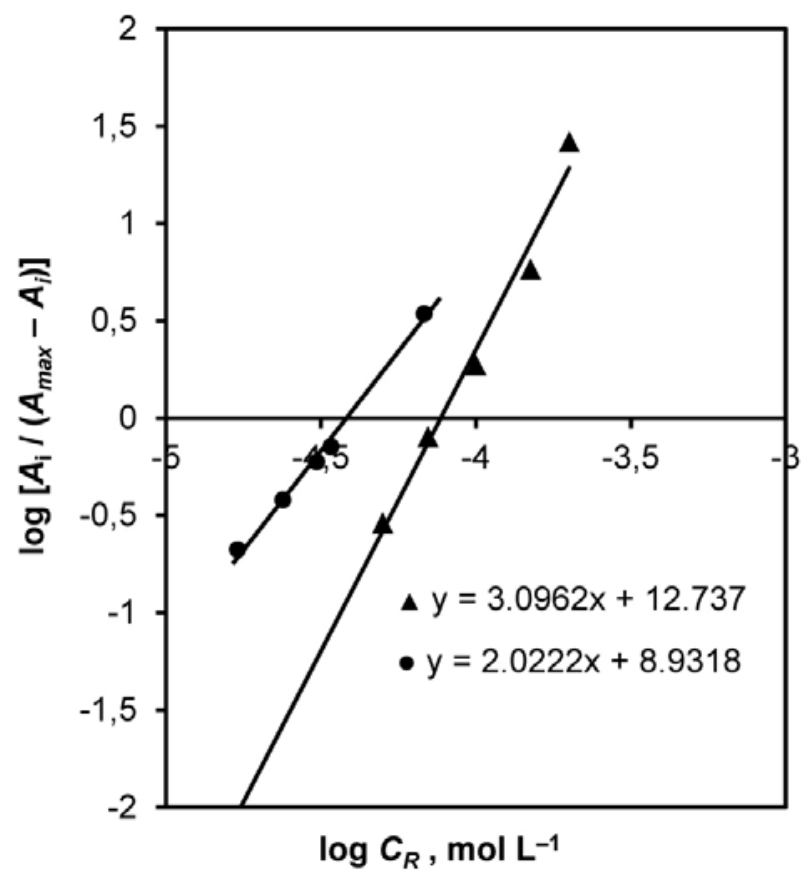

Figure 4. Straight lines by the mobile equilibrium method for determination of the molar ratios $\mathrm{Ge}(\mathrm{IV}): 4-\mathrm{NC}$ and $\mathrm{Ge}(\mathrm{IV}): \mathrm{Nt}$; $C_{\mathrm{Ge}(\mathrm{IV})}=2.0 \times 10^{-5} \mathrm{~mol} \mathrm{~L}^{-1} ; \mathrm{pH}=4.0 ; \lambda=405 \mathrm{~nm} ; \tau=2 \min \boldsymbol{\Delta}$ $\mathrm{Ge}(\mathrm{IV}): 4-\mathrm{NC}, C_{\mathrm{Nt}}=1.7 \times 10^{-4} \mathrm{~mol} \mathrm{~L}^{-1} ; \bullet \mathrm{Ge}(\mathrm{IV}): \mathrm{Nt}, C_{4-\mathrm{NC}}=5.0$ $\times 10^{-4} \mathrm{~mol} \mathrm{~L}^{-1}$

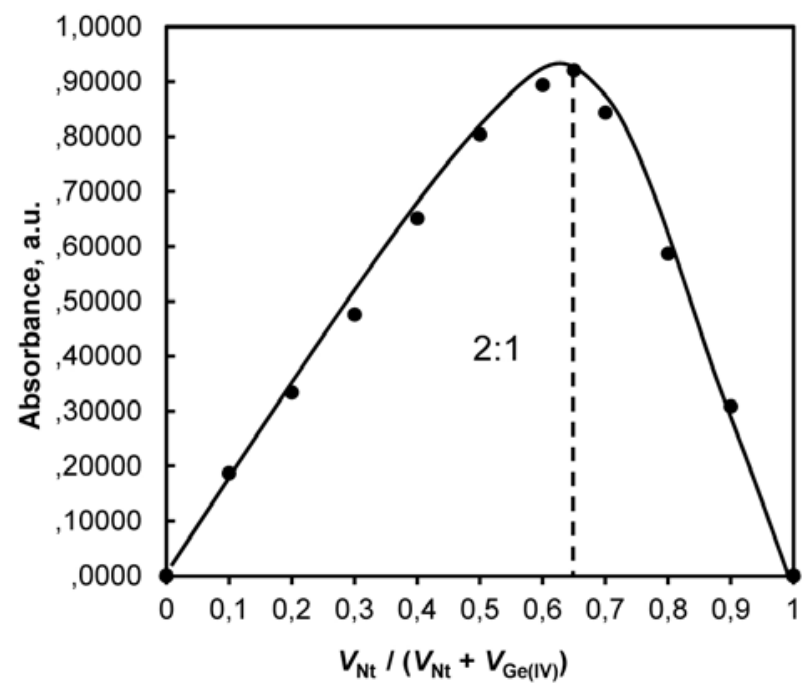

Figure 5. Determination of the molar ratio (n) Ge(IV): Nt by the method of continuous variations. $C_{\mathrm{Ge}(\mathrm{IV})}+C_{\mathrm{Nt}}=1.0 \times 10^{-3} \mathrm{~mol} \mathrm{~L}^{-1}$; $C_{4-\mathrm{NC}}=5.0 \times 10^{-4} \mathrm{~mol} \mathrm{~L}^{-1} ; \mathrm{pH}=4.0 ; \lambda=405 \mathrm{~nm} ; \tau=2 \mathrm{~min}$

Germanates containing $\left[\mathrm{Ge}(\mathrm{OH})_{6}\right]^{2-}$ ions are already described in the literature although in dilute aqueous solutions the major determinate ions appear to be [Ge$\left.\mathrm{O}(\mathrm{OH})_{3}\right]^{-},\left[\mathrm{GeO}_{2}(\mathrm{OH})_{2}\right]^{2-}$ and $\left\{\left[\mathrm{Ge}(\mathrm{OH})_{4}\right]_{8}(\mathrm{OH})_{3}\right\}^{3-9}$. The carried out experiments showed that the complex formation and the extraction of the ion-associated complex have occurred in dilute solutions and the molar ratio establis- hed by the independent methods mentioned above was is $\mathrm{Ge}(\mathrm{IV}): 4-\mathrm{NC}: \mathrm{Nt}=1: 3: 2$. Therefore, the complex formation of anionic chelate $\mathrm{Ge}(\mathrm{IV})-4-\mathrm{NC}$ can be given by equation (1):

$$
\begin{aligned}
& {\left[\mathrm{GeO}_{2}(\mathrm{OH})_{2}\right]^{2-}(\mathrm{aq})+} \\
& 3(\mathrm{HO})_{2} \mathrm{C}_{6} \mathrm{H}_{3}\left(\mathrm{NO}_{2}\right)(\mathrm{aq}) \rightarrow \\
& \left\{\mathrm{Ge}\left[\mathrm{O}_{2} \mathrm{C}_{6} \mathrm{H}_{3}\left(\mathrm{NO}_{2}\right)\right]_{3}\right\}^{2-}(\mathrm{aq})+4 \mathrm{H}_{2} \mathrm{O}
\end{aligned}
$$

Having in mind the reaction of chelate formation of $\mathrm{Ge}(\mathrm{IV})-4-\mathrm{NC}$ and molar ratio indicated above, it can be suggested that the formation of the ion-associate in the aqueous phase, its distribution between the aqueous and the organic phases and its extraction in chloroform can be given by the following equations (2-4).

$$
\begin{aligned}
& 2(\mathrm{Nt})^{+}(\mathrm{aq})+\left\{\mathrm{Ge}_{2}\left[\mathrm{O}_{2} \mathrm{C}_{6} \mathrm{H}_{3}\left(\mathrm{NO}_{2}\right)\right]_{3}\right\}^{2-}(\mathrm{aq}) \rightleftharpoons \\
& (\mathrm{Nt})_{2}\left\{\mathrm{Ge}\left[\mathrm{O}_{2} \mathrm{C}_{6} \mathrm{H}_{3}\left(\mathrm{NO}_{2}\right)\right]_{3}\right\}(\mathrm{aq}) \\
& (\mathrm{Nt})_{2}\left\{\mathrm{Ge}\left[\mathrm{O}_{2} \mathrm{C}_{6} \mathrm{H}_{3}\left(\mathrm{NO}_{2}\right)\right]_{3}\right\}(\mathrm{aq}) \rightleftharpoons \\
& (\mathrm{Nt})_{2}\left\{\mathrm{Ge}\left[\mathrm{O}_{2} \mathrm{C}_{6} \mathrm{H}_{3}\left(\mathrm{NO}_{2}\right)\right]_{3}\right\}(\mathrm{org}) \\
& \\
& 2(\mathrm{Nt})^{+}(\mathrm{aq})+\left\{\mathrm{Ge}_{2}\left[\mathrm{O}_{2} \mathrm{C}_{6} \mathrm{H}_{3}\left(\mathrm{NO}_{2}\right)\right]_{3}\right\}^{2-}(\mathrm{aq}) \rightleftharpoons \\
& (\mathrm{Nt})_{2}\left\{\mathrm{Ge}\left[\mathrm{O}_{2} \mathrm{C}_{6} \mathrm{H}_{3}\left(\mathrm{NO}_{2}\right)\right]_{2}\right\}(\mathrm{org})
\end{aligned}
$$

Hence, the ion-pair formed between the anionic chelate of $\mathrm{Ge}(\mathrm{IV})-4-\mathrm{NC}$ and the nitronium cation can be represented by the general formula $(\mathrm{Nt})_{2}\left\{\mathrm{Ge}\left[\mathrm{O}_{2} \mathrm{C}_{6} \mathrm{H}_{3}\right.\right.$ $\left.\left.\left(\mathrm{NO}_{2}\right)\right]_{3}\right\}$.

\section{5. Extraction Equilibria, True Molar Absorptivity and Recovery Factor}

The association process in aqueous phase and the extraction equilibria were investigated and quantitatively characterized with respect to the following key constants: association constant, distribution constant, extraction constant and recovery factor.

The association constant $\beta$ was determined by the method of Komar-Tolmachev from equation (5). ${ }^{41}$

$$
\beta=(1 / \mathrm{n})^{\mathrm{n}} /\left[\varepsilon(\operatorname{tg} \alpha)^{\mathrm{n}+1}\right]
$$

where 1 is the cuvette thickness $(1=1 \mathrm{~cm}) ; \mathrm{n}$ is the molar ratio between the components independently determined (e.g. by the mobile equilibrium method, the straight-line method of Asmus or the method of continuous variations) $(\mathrm{n}=2), \varepsilon$ is the true molar absorptivity.

The true molar absorptivity $\varepsilon$ was determined by the method of Komar-Tolmachev (Figure 6) from the equation of a straight line $\mathrm{Y}=2.1644 \mathrm{X}+3.2386(\varepsilon=1 / \mathrm{b} \times$ $\left.10^{-5}\right)$ and its value is given in Table 1 , column $2 .{ }^{41}$

The distribution constant $\left(K_{D}\right)$ was determined by equation (6), where $A_{1}$ and $A_{3}$ are the absorbance (measured against blanks) obtained after a single and triple extraction, respectively. 


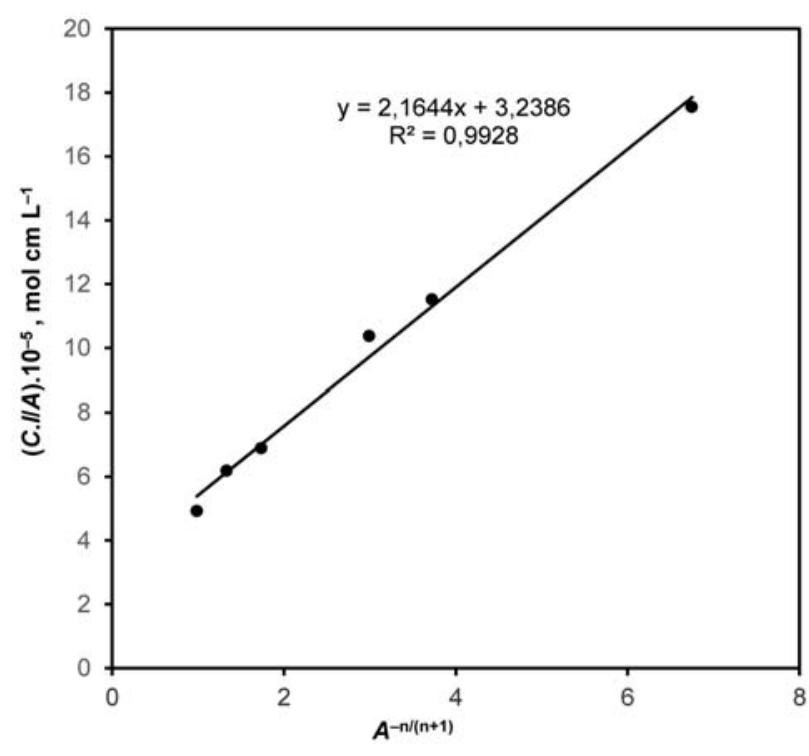

Figure 6. Dependency of $(C . l / A)$ on $A^{-\mathrm{n} /(\mathrm{n}+1)}$ (method of Komar-Tolmachev). $C=C_{\mathrm{Ge}(\mathrm{IV})} \mathrm{mol} \mathrm{L}^{-1} ; C_{\mathrm{Nt}}=2 C_{\mathrm{Ge}(\mathrm{IV})} \mathrm{mol} \mathrm{L}^{-1} ; C_{4-\mathrm{NC}}$ $=5.0 \times 10^{-4} \mathrm{~mol} \mathrm{~L}^{-1} ; A-$ absorbance; $l-$ cell thickness, $l=1 \mathrm{~cm}$; $\mathrm{n}=2$

$$
\begin{aligned}
& K_{D}=\left\{(\mathrm{Nt})_{2}\left\{\mathrm{Ge}\left[\mathrm{O}_{2} \mathrm{C}_{6} \mathrm{H}_{3}\left(\mathrm{NO}_{2}\right)\right]_{3}\right\}\right\}(\text { org }) / \\
& \left\{(\mathrm{Nt})_{2}\left\{\mathrm{Ge}\left[\mathrm{O}_{2} \mathrm{C}_{6} \mathrm{H}_{3}\left(\mathrm{NO}_{2}\right)\right]_{3}\right\}\right\}(\mathrm{aq})=A_{1} /\left(A_{3}-A_{I}\right)
\end{aligned}
$$

The recovery factor was determined from the equation (7):

$$
R \%=100 K_{D} /\left(K_{D}+1\right)
$$

The extraction constant $K_{e x}$ was calculated by two independent methods:

$$
\text { (i) } \log K_{e x}=\log K_{D}+\log \beta
$$

where $\beta$ was determined by the method of Komar-Tolmachev.

(ii) the method of Likussar-Boltz: ${ }^{42}$
The method of Likussar-Boltz uses the data from the method of continuous variations (Figure 5). The extraction constant $K_{e x}$ was calculated by the equation of Likussar-Boltz for molar ratio 1:2 (equation 9):

$$
\begin{aligned}
& \log K_{e x}=0,3522-2 \log K+\log \mathrm{Y}_{\max } \\
& -3 \log \left(1-\mathrm{Y}_{\max }\right)
\end{aligned}
$$

where $K$ is the total concentration of reagents ( $K=C_{\mathrm{Ge}(\mathrm{IV})}$ $\left.+C_{\mathrm{Nt}}=1.0 \times 10^{-3} \mathrm{~mol} \mathrm{~L}^{-1}\right) ; \mathrm{Y}_{\max }$ and $\left(1-\mathrm{Y}_{\max }\right)$ are determined from the additionally plotted normalized absorption curve $\left(\mathrm{Y}_{\max }=0.933 ;\left(1-\mathrm{Y}_{\max }\right)=0.067\right)$.

The values of the equilibrium constants and the recovery factor are presented in Table 3. The results obtained by independent methods are statistically dissimilar and confirm the proposed scheme of the process of complex formation of the ion-pair in the aqueous phase, its distribution between the aqueous and the organic phases and its extraction in chloroform.

\section{Conclusion}

The extraction equilibria for complex formation of the ion-pair formed between the anionic chelate of Ge(IV)-4-nitrocatechol (4-NC) and the cation of 1,4-diphenyl-3-(phenylamino)-1H-1,2,4-triazole (Nitron, Nt) was studied by spectrophotometry. The processes of the chelate formation and extraction of the ion-associated complex Ge(IV)-4-NC-Nt into chloroform were investigated. The optimum conditions for the association in aqueous phase and extraction of the ion-associated complex were established. The validity of Beer's law was checked and a linear relationship between the germanium(IV) concentration in the aqueous phase and the absorbance of the

\begin{tabular}{|c|c|}
\hline Equilibrium Constant and Recovery Factor & Value \\
\hline $\begin{array}{l}\text { Equilibrium (equation 3) - Association constant } \beta \\
\beta=(\mathrm{Nt})_{2}\left\{\mathrm{Ge}\left[\mathrm{O}_{2} \mathrm{C}_{6} \mathrm{H}_{3}\left(\mathrm{NO}_{2}\right)\right]_{3}\right\}(\mathrm{aq}) /\left\{\left[(\mathrm{Nt})^{+}\right]^{2}(\mathrm{aq})\right.\end{array}$ & $\begin{array}{l}\log \beta=(8.90 \pm 0.75)^{\mathrm{a}} \\
\log \beta=(9.47 \pm 0.21)^{\mathrm{b}}\end{array}$ \\
\hline$\left.\left\{\left\{\mathrm{Ge}\left[\mathrm{O}_{2} \mathrm{C}_{6} \mathrm{H}_{3}\left(\mathrm{NO}_{2}\right)\right]_{3}\right\}^{2-}\right\}(\mathrm{aq})\right\}$ & \\
\hline $\begin{array}{l}\text { Equilibrium (equation 4) - Distribution constant } K_{D} \\
K_{D}=\left\{\left(\mathrm{Nt}_{2}\left\{\mathrm{Ge}_{2}\left[\mathrm{O}_{2} \mathrm{C}_{6} \mathrm{H}_{3}\left(\mathrm{NO}_{2}\right)\right]_{3}\right\}\right\}(\text { org }) /\left\{(\mathrm{Nt})_{2}\left\{\mathrm{Ge}_{2}\left[\mathrm{O}_{2} \mathrm{C}_{6} \mathrm{H}_{3}\left(\mathrm{NO}_{2}\right)\right]_{3}\right\}\right\}(\mathrm{aq})\right. \\
\left\{\mathrm{Ge}\left[\mathrm{O}_{2} \mathrm{C}_{6} \mathrm{H}_{2}\left(\mathrm{NO}_{2}\right)\right]_{3}\right\}(\mathrm{ag})\end{array}$ & $\log K_{D}=(1.30 \pm 0.01)^{\mathrm{c}}$ \\
\hline Equilibrium (equation 5) - Extraction constant $K$ & $\log K_{e x}=(10.20 \pm 0.76)$ \\
\hline $\begin{array}{l}K_{e x}=\left\{(\mathrm{Nt})_{2}\left\{\mathrm{Ge}\left[\mathrm{O}_{2} \mathrm{C}_{6} \mathrm{H}_{3}\left(\mathrm{NO}_{2}\right)\right]_{2}\right\}\right\}(\mathrm{org}) /\left\{\left\{[\mathrm{Nt}]^{+e}\right\}^{2}(\mathrm{aq})\right. \\
\left.\times\left\{\left\{\mathrm{Ge}\left[\mathrm{O}_{2} \mathrm{C}_{6} \mathrm{H}_{3}\left(\mathrm{NO}_{2}\right)\right]_{3}\right\}^{2-}\right\}(\mathrm{aq})\right\}\end{array}$ & $\log K_{e x}^{e x}=(9.85 \pm 0.45)^{\mathrm{e}}$ \\
\hline Recovery factor $R \%$ & $R=(95.21 \pm 0.03) \%^{\mathrm{f}}$ \\
\hline
\end{tabular}
ion-association complex in the organic phase extraction was observed for concentrations up to $5.81 \mu \mathrm{g} \mathrm{mL}-1$ $\mathrm{Ge}(\mathrm{IV})$. The presence of hydrophobic substituents, phenyl groups in the molecule of the triazole, increased the solu-

Table 3. Values of the Equilibrium Constants and the Recovery Factor

${ }^{a}$ Calculated by Komar-Tolmachev method (equation.(6)); ${ }^{\mathrm{b}}$ Calculated by Holme-Langmyhr method; ${ }^{42 \mathrm{c}}$ Calculated by equation (6); ${ }^{\mathrm{d}}$ Calculated by equation. (8), where $\beta$ is determined by the Komar-Tolmachev method; ${ }^{\mathrm{e}}$ Calculated by Likussar-Boltz method (equation (9)); ${ }^{\mathrm{f}}$ Calculated by equation (7). 
bility of the ion-associated complex in the organic solvent. The molar ratio of the components, determined by independent methods, shows that the ion-associated complex could be represented with the general formula $(\mathrm{Nt})_{2}\left\{\mathrm{Ge}\left[\mathrm{O}_{2} \mathrm{C}_{6} \mathrm{H}_{3}\left(\mathrm{NO}_{2}\right)\right]_{3}\right\}$. A corresponding reaction scheme of the complex was also suggested. The equilibrium constants and analytical characteristics needed for the quantitative assessment of the extraction equilibrium were calculated, i.e. the association constant $(\beta)$, the distribution constant $\left(K_{D}\right)$, the extraction constant $\left(K_{e x}\right)$, the recovery factor $(R)$, the apparent molar absorptivity $\left(\varepsilon^{\prime}\right)$, the true molar absorptivity $(\varepsilon)$, the limit of detection $(L O D)$, the limit of quantification $(L O Q)$ and the Sandell's sensitivity $(S S)$. From the analytical characteristics of the extraction system $\mathrm{Ge}(\mathrm{IV})-4-\mathrm{NC}-\mathrm{Nt}-\mathrm{H}_{2} \mathrm{O}-\mathrm{CHCl}_{3}$, it can be concluded that the ion-pair formed between the anionic chelate of $\mathrm{Ge}(\mathrm{IV})-4-\mathrm{NC}$ and the nitronium cation allows determinations of Ge(IV) with a high sensitivity.

\section{Acknowledgements}

The authors would like to thank the Research Fund of the University of Plovdiv for the financial support of the current research.

\section{References}

1. R. R. Moskalyk, Miner. Eng. 2004, 17, 393-402. http://dx.doi.org/10.1016/j.mineng.2003.11.014

2. L. Cao L, J. Park, P. Fan, B. Clemens, M. L. Brongersma, NanoLett. 2010, 10, 1229-1233. http://dx.doi.org/10.1021/n1903727

3. S. Goodman, Med. Hypoth. 1988, 26, 207-215. http://dx.doi.org/10.1016/0306-9877(88)90101-6

4. K. W. Yu, H. N. Murthy, C. S. Jeong, E. J. Hahn, K. Y. Paek, Process Biochem. 2005, 40, 2959-2961. http://dx.doi.org/10.1016/j.procbio.2005.01.015

5. T. Matsusaka, M. Fujii, T. Nakano, T. Terai, A. Kurata, M. Imaizumi, H. Abe, Clin. Nephrol. 1988, 30, 341-345.

6. S. H. Tao, P. M. Bolger, Regul. Toxicol. Pharmacol. 1997, 25, 211-219.

7. T. Sanai, S. Okuda, K. Onoyama, N. Oochi, Y. Oh, K. Kobayashi, K. Shimamatsu, S. Fujimi, M. Fujishima, Nephron 1990, 54, 53-60. http://dx.doi.org/10.1159/000185810

8. A. G. Shauss, Ren. Fail. 1991, 13, 1-4. http://dx.doi.org/10.3109/08860229109022139

9. F. A. Cotton, G. Wilkinson, C. A. Murillo, M. Bochmann: Advanced Inorganic Chemistry, Wiley Publishers, New Jersey, 1999, pp. 392-394.

10. V. V. Skopenko, A. Y. Tsivadze, L. I. Sabranskiy, A. D. Garnovskiy: Coordination Chemistry, Akademkniga, Moscow, Russia, 2007, pp. 78-81.

11. V. S. Sergienko, L. K. Minacheva, A. V. Churakov, Rus. J.
Inorg. Chem. 2010, 55, 2001-2030.

http://dx.doi.org/10.1134/S0036023610130012

12. W. Levason, G. Reid, W. Zhang, Coordin. Chem. Rev. 2011, 255, 1319-1341.

http://dx.doi.org/10.1016/j.ccr.2010.11.019

13. M. F. Davis, W. Levason, G. Reid, M. Webster, Dalt. Trans. 2008, 17, 2261-2269.

http://dx.doi.org/10.1039/B716765B

14. I. I. Seifullina, N. V. Shmatkova, E. E. Martsinko, Russ. J. Coordin. Chem. 2010, 30, 214-220. http://dx.doi.org/10.1023/B:RUCO.0000022120.49644.5c

15. F. Cheng, M. F. Davis, A. L. Hector, W. Levason, G. Reid, M. Webster, W. Zhang, Eur. J. Inorg. Chem. 2007, 2007, 2488-2495. http://dx.doi.org/10.1002/ejic.200700233

16. G. S. Pokrovski, F. Martin, J. L. Hazemann, J. Schott, Chem. Geol. 2000, 163, 151-165.

http://dx.doi.org/10.1016/S0009-2541(99)00102-3

17. D. Biller, C. Burschka, M. Penka, R. Tacke, Inorg. Chem. 2002, 41, 3901-3908. http://dx.doi.org/10.1021/ic0255757

18. V. A. Nazarenko: Analytical Chemistry of Germanuim, Nauka, Moscow, Russia, 1973, pp. 29-54.

19. I. I. Seifullina, A. G. Pesaroglo, L. K. Minacheva, E. E. Martsinko, V. S. Sergienko, Russ. J. Inorg. Chem. 2006, 51, 1892-1899. http://dx.doi.org/10.1134/S0036023606120096

20. L. Zaijun, P. Jiaomai, T. Jan, Anal. Chim. Acta 2001, 445, 153-159. http://dx.doi.org/10.1016/S0003-2670(01)01259-4

21. F. N. Shi, L. C. Silva, M. J. Hardie, T. Trindade, F. A. Paz, J. Rocha, Inorg. Chem. 2007, 46, 6502-6515. http://dx.doi.org/10.1021/ic700507j

22. F. A. Torralvo, C. Fernandez-Pereira, M. C. Campanario, Ind. Eng. Chem. Res. 2010, 49, 4817-4823. http://dx.doi.org/10.1021/ie901020f

23. S. Jagatap, S. Kolekar, S. Han, M. Anuse, Inter. J. Anal. Bioan. Chem. 2012, 2, 235-240.

24. K. T. Mahmudov, R. A. Aliyeva, S. Z. Hamidov, F. M. Chyragov, S. R. Mardanova, M. N. Kopylovich, A. J. L. Pombeiro, Am. J. Anal. Chem. 2012, 3, 790-799. http://dx.doi.org/10.4236/ajac.2012.312105

25. K. Gavazov, A. Dimitrov, V. Lekova, Russ. Chem. Rev. 2007, 76, 169-179. http://dx.doi.org/10.1070/RC2007v076n02ABEH003655

26. C. Farber, M. Leibold, C. Bruhn, M. Maurer, U. Siemeling, Chem. Commun. 2012, 48, 227-229. http://dx.doi.org/10.1039/C1CC16460K

27. V. S. Archer, R. B. Twelves, Talanta 1968, 15, 47-54. http://dx.doi.org/10.1016/0039-9140(68)80006-2

28. Th. Koralewski, G. A. Parkar, Anal. Chim. Acta 1980, 113, 389-392. http://dx.doi.org/10.1016/S0003-2670(01)93757-2

29. P. Racheva, K. Gavazov, V. Lekova, A. Dimitrov, J. Materials 2013, 2013, Article ID 897343, 7 pages.

http://dx.doi.org/10.1155/2013/897343

30. K. Stojnova, V. Divarova, P. Racheva, G. Daskalov, V. Leko- 
va, Monatsh. Chem. 2015, 146, 867-873. http://dx.doi.org/10.1007/s00706-014-1402-7

31. M. J. Moorcroft, J. Davis, R. G. Compton, Talanta 2001, 54, $785-803$. http://dx.doi.org/10.1016/S0039-9140(01)00323-X

32. S. Shahine, I. Nazara, Microchim. Acta 1976, 66, 75-79. http://dx.doi.org/10.1007/BF01257096

33. S. Shahine, S. Khamis, Microchem. J. 1980, 25, 46-47. http://dx.doi.org/10.1016/0026-265X(80)90240-4

34. R. Koroda, N. Yoshikuni, Microchim. Acta 1974, 62, 653-662. http://dx.doi.org/10.1007/BF01218202

35. A. K. Babko, A. T. Pilipenko: Photometric Analysis, Khimiya, Moscow, Russia, 1968, pp. 159-164.

36. V. A. Mikhaylov: Extraction Chemistry, Nauka, Novosibirsk, Russia, 1984, pp. 194-249.

37. G. Kristian: Analytical Chemistry, BINOM, Moscow, Russia, 2009, pp. 414-426.

38. U. A. Zolotov, V. A. Bodnya, A. N. Zagrusina, H. Freiser, Anal. Chem. 1982, 14, 93-174. http://dx.doi.org/10.1080/10408348208542772

39. K. Stojnova, P. Racheva, V. Divarova, K. Bozhinova, V. Lekova, Acta Chim. Slov. 2016, 63, 654-660. http://dx.doi.org/10.17344/acsi.2016.2513

40. V. Divarova, K. Stojnova, P. Racheva, V. Lekova, Acta Chim. Slov. 2016, 63, 97-103. http://dx.doi.org/10.17344/acsi.2015.1987

41. Z. Marczenko, M. Baltcerzak: UV-Vis Spectrophotometric Methods Applied to the Inorganic Analysis, BINOM, Moscow, Russia, 2009, pp. 169-174.

42. B. F. Quin, R. R. Brooks, Anal. Chim. Acta 1975, 74, 75-84. http://dx.doi.org/10.1016/S0003-2670(01)82781-

43. M. I. Bulatov, I. P. Kalinkin: Practical Handbook on Photometric Methods of Analysis, Khimiya, Leningrad, Russia, 1986, pp. 174-264.

44. W. Likussar, D. F. Boltz, Anal. Chem 1971, 43, 1265-1272. http://dx.doi.org/10.1021/ac60304a006

45. A. Holme, F. J. Langmyhr, Anal. Chim. Acta 1966, 36, 383391. http://dx.doi.org/10.1016/0003-2670(66)80066-1

\section{Povzetek}

S pomočjo spektrofotometrije smo proučili tvorbo komplekso med anionskim kelatnim kompleksom Ge(IV)-4-nitrokatehol (4-NC) in kationom 1,4-difenil-3-(fenilamino)-1H-1,2,4-triazolom (Nitron, Nt) v tekočina-tekočina ekstrakcijskem sistemu $\mathrm{Ge}(\mathrm{IV})-4-\mathrm{NC}-\mathrm{Nt}-\mathrm{H}_{2} \mathrm{O}-\mathrm{CHCl}_{3}$. Določili smo optimalne ekstrakcijsko-spektrofotometrične pogoje za tvorbo kompleksov. Preverjena je bila veljavnost Beerovega zakona ter izračunane nekatere analizne karakteristike. Določen je bil tudi vpliv različnih ionov in reagentov na proces tvorbe kompleksov. Asociacijski proces v vodni fazi in ekstrakcijsko ravnotežje je bilo proučeno in kvantitativno okarakterizirano. Sledeče najpomembnejše konstante procesov so bile izračunane: asociacijska konstanta, distribucijska konstanta, ekstrakcijska konstanta in izkoristek ekstrakcije. Z neodvisnimi metodami smo določili molske deleže. Predlagana je reakcijska shema, splošna formula in struktura kompleksa. 